\title{
Review: Potensi Pengembangan Pertanian Perkotaan oleh Lanjut Usia untuk Mendukung Ketahanan Pangan
}

\author{
Reni Nurjasmi \\ Program Studi Agroteknologi Fakultas Pertanian Universitas Respati Indonesia Jakarta \\ Email: reni_nurjasmi@urindo.ac.id
}

\begin{abstract}
Abstrak
Pertanian perkotaan merupakan sebuah industri yang memproduksi, memproses, dan menjual bahan makanan dalam rangka memenuhi permintaan harian konsumen dalam kota dan pinggiran kota melalui penerapan metode produksi intensif, menggunakan sumber daya alam dan limbah perkotaan untuk menghasilkan berbagai macam tanaman dan ternak. Paradigma peran pertanian perkotaan telah bergeser pada tataran peran yang lebih strategis, yakni sebagai pendukung ketahanan pangan dan keamanan pangan kota serta sekitar kota. Implementasi pertanian perkotaan yang dilakukan secara penuh di setiap kota besar dunia akan menghasilkan 180 juta ton bahan makanan selama setahun. Angka tersebut merupakan 10 persen dari total hasil produksi makanan secara global. Meskipun saat ini banyak masyarakat yang menaruh minat pada pertanian perkotaan namun jumlahnya masih jauh dari mencukupi kebutuhan pangan masyarakat, akibatnya hingga saat ini pasokan pangan perkotaan masih sangat bergantung pada perdesaan maupun kawasan pinggir kota bahkan beberapa produk pangan merupakan produk impor. Populasi lansia di perkotaan mengalami peningkatan 52,80 persen dibandingkan di perdesaan yaitu 47,20 persen. Diprediksi pada tahun 2050 populasi lansia mencapai 25 persen dari total populasi penduduk Indonesia. Potensi ini harus menjadi peluang untuk mengembangkan pertanian perkotaan melalui pemberdayaan lansia untuk mewujudkan ketahanan pangan. Berbagai teknologi pertanian perkotaan dapat menjadi pilihan bagi lansia untuk bercocok tanam namun yang paling direkomendasikan adalah model vertikultur atau bertingkat. Pertanian perkotaan juga berdampak positif bagi kesehatan fisik dan mental yaitu menurunkan tingkat stres, meningkatkan serotin, meningkatkan kesehatan jantung dan mengurangi risiko stroke, meningkatkan kesehatan otak, meningkatkan mobilitas, dan meningkatkan kebutuhan nutrisi dan gizi.
\end{abstract}

Kata Kunci: Pertanian Perkotaan, Lanjut Usia, Ketahanan Pangan

\begin{abstract}
Urban agriculture is an industry that produces, processes and sells food ingredients in order to meet the daily demands of consumers in cities and suburbs through the application of intensive production methods, using natural resources and urban waste to produce a wide variety of crops and livestock. The paradigm of the role of urban agriculture has shifted to a more strategic role, namely as a supporter of food security and food security in cities and around cities. Fully implemented urban agriculture in every major city in the world will produce 180 million tons of food for a year. This figure represents 10 percent of the total global food production. Although currently many people are interested in urban agriculture, the amount is still far from sufficient for the community's food needs, as a result, until now the urban food supply is still very dependent on rural and suburban areas and even some food products are imported products. The elderly population in urban areas has increased by 52.80 percent compared to 47.20 percent in rural areas. It is predicted that in $\mathbf{2 0 5 0}$ the elderly population will reach 25 percent of the total population of Indonesia. This potential should be an opportunity to develop urban agriculture through empowering the elderly to achieve food security. Various urban agricultural technologies
\end{abstract}

\section{http://ejournal.urindo.ac.id/index.php/pertanian}

Article History :

Sumbitted 10 Juni 2021, Accepted 30 Juni2021, Published 30 Juni2021 
can be an option for the elderly to cultivate crops, but the most recommended is the vertical or terraced model. Urban agriculture also has a positive impact on physical and mental health by reducing stress levels, increasing serotonin, improving heart health and reducing the risk of stroke, improving brain health, increasing mobility, and increasing nutritional and nutritional needs.

Keywords: Urban Agriculture, Elderly, Food Security

\section{PENDAHULUAN}

Persoalan penduduk yang berusia lanjut dialami banyak negara, termasuk Indonesia. Ini merupakan siklus yang biasa terjadi. Penduduk yang sebelumnya masuk kategori usia produktif, di kisaran usia 20 59 tahun dan bekerja sebagai pegawai negeri sipil (PNS) maupun karyawan swasta, ketika sudah berusia 60 tahun dan sudah pensiun, pada umumnya mengalami penurunan produktivitas. Mereka sudah termasuk kategori penduduk lanjut usia (lansia). Meski demikian, para lansia tersebut masih dapat produktif bila ada aktivitas yang sesuai dengan usia mereka yang sudah tidak lagi muda. Salah satu aktivitas produktif yang tepat bagi para lansia adalah aktivitas pertanian perkotaan.

Pertanian perkotaan bisa dikerjakan pada lahan yang tidak terlalu luas sehingga para lansia tidak perlu melakukan aktivitas berat yang tentu bisa berdampak pada kesehatan tubuh mereka. Sebagai gambaran, bila lansia memiliki pekarangan seluas $1 \times 2$ meter pun sudah bisa menggarap pertanian perkotaan. Prinsip dasar urban faming adalah aktivitas pertanian pada lahan yang terbatas atau sempit. Pertanian perkotaan yang diusahakan pada lahan yang lebih luas bisa menjadi kegiatan berskala bisnis besar dan menguntungkan.

Berdasarkan data Badan Pusat Statistik (BPS) pada Susenas Maret 2019, penduduk lansia tahun 2019 telah mencapai 25,66 juta jiwa atau 9,60 persen dari total jumlah penduduk Indonesia. Keberadaan penduduk lansia tersebar baik di perkotaan maupun perdesaan. Lansia yang tinggal di perkotaan lebih tinggi dari perdesaan $(52,80$ persen berbanding 47,20 persen). Bila lansia yang berada di perkotaan tersebut melakukan kegiatan pertanian perkotaan, setidaknya mereka bisa memenuhi kebutuhan sayuran bagi rumah tangga masing-masing. Jenis tanaman yang dapat dibudidakan menggunakan teknologi pertanian perkotaan sangat beragam mulai dari tanaman sayuran seperti kangkung, selada, pakcoy, sawi, bayam, terung, cabai, bawang, tomat, paprika hingga tanaman buah-buahan seperti melon, semangka, lemon, anggur, dan masih banyak lagi. Bahkan bila pertanian perkotaan dikerjakan serius dan berkelanjutan, para lansia tersebut bisa berkontribusi membangun 
ketahanan pangan yang tengah dilakukan pemerintah [1].

Oleh karena itu, kegiatan pertanian perkotaan yang dilakukan para lansia jangan dipandang sebelah mata karena berpotensi mendukung ketahanan pangan yang merupakan salah satu program pemerintah dalam membangun kedaulatan sebuah bangsa. Tidak bisa dibayangkan bila untuk memenuhi kebutuhan pangan saja sebuah negara sangat bergantung pada impor pangan dari negara lain. Tentu kondisi ini sangat berbahaya bagi kedaulatan sebuah bangsa dan kita tidak berharap hal tersebut terjadi pada Indonesia, negeri yang gemah ripah loh jinawi dengan potensi pertanian amat besar.

Dalam merealisasikan kedaulatan pangan dan keberlanjutan swasembada pangan, yang patut diwaspadai adalah pertambahan jumlah penduduk. Jumlah penduduk Indonesia tahun 2035 diprediksi mencapai 440 juta jiwa, atau mengalami pertumbuhan $1,3 \%-1,5 \%$ per tahun[2]. Jumlah penduduk tersebut tidak berbanding lurus dengan ketersediaan lahan. Untuk itu, adanya bonus demografi saat ini seharusnya disikapi secara serius sehingga ketersediaan pangan secara mandiri dalam jumlah memadai dapat tercapai dengan dukungan pemerintah serta pihak terkait.

Di sisi lain, gencarnya pembangunan industri di negeri ini meski berdampak positif namun juga menimbulkan dampak negatif secara langsung dan tidak langsung. Diantaranya berkurangnya lahan pertanian, berkurang daya serap tenaga kerja pada sektor pertanian, serta terjadi perubahan mata pencaharian penduduk setempat dari sektor pertanian ke industri dan jasa, serta perdagangan. Artinya, jumlah penduduk yang menangani pertanian menjadi berkurang. Data Kementerian Pertanian (Kementan) menunjukan sebanyak 60.000 hektar lahan pertanian di Indonesia menyusut setiap tahunnya. Penyusutan tersebut disebabkan oleh alih fungsi lahan ke area non pertanian. Peralihan fungsi dilakukan untuk proyek pembangunan jangka panjang seperti kompleks perumahan, pembangunan pabrik, fasilitas jalan tol hingga fasilitas umum fisik lainnya. Padahal penyusutan lahan seluas itu nyaris setara dengan angka penurunan produksi sebanyak 300.000 ton produksi pertanian setiap tahun [3].

Kementan tidak tinggal diam dengan melakukan berbagai upaya pencegahan dengan memperhatikan daya dukung dan daya tampung lingkungan hidup. Langkah itu dilakukan untuk bisa mengkontrol dan menjaga keseimbangan semua aspek, termasuk ekonomi, sosial masyarakat, dan ekologis dalam pengelolaan sumberdaya alam dan lingkungan hidup. Ketika pemanfaatan lahan melampaui daya dukungnya, maka alam bukan lagi menjadi sumber daya melainkan bencana. Karena itu 
perlu ada pengaturan keseimbangan antara alam dan kebutuhan ruang, termasuk perlindungan lahan pertanian dalam penataan ruang [3].

Menteri Pertanian Syahrul Yasin Limpo juga mengecam, bahkan mengingatkan bahwa kegiatan mengalihfungsikan lahan pertanian akan mendapat ancaman hukuman seperti diatur pada UU Nomor 41 Tahun 2009 tentang Perlindungan Lahan Pertanian Pangan Berkelanjutan. Adanya pengaturan pda UU tersebut bertujuan melindungi lahan pertanian pangan dari derasnya arus degradasi. Adapun Ketentuan yang dibangun dalam UU ini dimaksudkan agar bidang-bidang lahan tertentu hanya boleh digunakan untuk aktivitas pertanian pangan yang sesuai peruntukan. Regulasi tersebut juga menegaskan sanksi perorangan dan perusahaan yang melakukan pelanggaran terhadap alih fungsi lahan pertanian. Pasal 72, 73, dan 74 menerangkan dengan rinci denda dan hukuman bagi pelanggar UU tersebut [3].

\section{METODE PENELITIAN}

Penelitian merupakan penelitian studi literatur (literature review) dengan menelaah sumber pustaka dan dokumen terkait baik berupa jurnal, buku-buku atau laporan penelitian lainnya. Hasil dari berbagai telaah sumber pustaka dan dokumen digunakan untuk mengidentifikasi potensi pengembangan pertanian perkotaan oleh lanjut usia untuk mendukung ketahanan pangan perkotaan.

\section{HASIL DAN PEMBAHASAN}

\section{Keterbatasan Lahan Pertanian}

Bagi Indonesia yang memiliki populasi penduduk 267 juta dengan luas wilayah daratan 1.919 .440 kilometer persegi, ketersediaan pangan menjadi keharusan sehingga ketahanan pangan perlu direalisasikan. Salah satu upaya pemerintah membangun ketahanan pangan melalui program swasembada pangan. Hanya saja program tersebut tidak akan berjalan baik bila tidak didukung dengan ketersediaan lahan pertanian yang memadai. Di sisi lain, bila melihat realitas di lapangan, terjadi penyusutan jumlah lahan pertanian dari tahun ke tahun. Dalam konteks inilah lahan pangan menjadi permasalahan krusial bagi Indonesia.

Ancaman terhadap ketahanan pangan telah mengakibatkan Indonesia harus sering mengimpor produk-produk pangan untuk memenuhi kebutuhan dalam negeri. Dalam keadaan jumlah penduduk yang masih terus meningkat jumlahnya, ancaman-ancaman terhadap produksi pangan telah memunculkan kerisauan akan terjadi keadaan rawan pangan pada masa yang akan datang. Akibatnya dalam waktu yang akan datang Indonesia membutuhkan 
tambahan ketersediaan pangan dan lahan pangan.

Sangat kecil kemungkinan program swasembada pangan terwujud dengan optimal ketika lahan pertanian produktif berubah menjadi perumahan, pertokoan, serta kegiatan usaha lain yang justru tidak ada korelasinya dengan pertanian.

Terkait ketersediaan lahan pertanian, target swasembada pangan yang dicanangkan pemerintah sejatinya sulit untuk dicapai. Salah satu faktor penyebabnya adalah ketersediaan luas lahan pertanian yang kian tidak memadai. Bank Dunia menyebutkan, pada 2017 ternyata hanya $31,5 \%$ atau 570.000 kilometer persegi lahan di Indonesia yang digunakan untuk pertanian. Pemanfaatan lahan pertanian tersebut sangat tidak seimbang bila dibandingkan Thailand yang mampu mengoptimalkan lahan pertanian seluas 221.000 kilometer persegi atau $43,3 \%$ dari total lahan di negeri Gajah Putih tersebut [4].

Pemerintah mungkin perlu berkaca pada Australia yang serius mengarap sektor pertanian dengan menggunakan 52,9\% lahannya untuk pertanian atau seluas 4 juta kilometer persegi. hal sama dilakukan Tiongkok yang berpenduduk terbanyak di dunia yaitu1,5 miliar jiwa yang memiliki lahan pertanian seluas 5 juta kilometer persegi atau $54,8 \%$ dari total luas lahan yang ada. Berdasarkan data di atas, terlihat perbandingan rasio penduduk dengan lahan di Indonesia adalah 1 orang berbanding 0,22 hektar, Thailand 1 orang berbanding 0,32 hektar, Australia 1 orang berbanding 16,67 hektar dan Tiongkok 1 orang berbanding 0,35 hektar [4].

Terjadinya konversi lahan pertanian menjadi non pertanian di Indonesia ternyata membawa dampak buruk terhadap pembangunan dan ketahanan pangan nasional. Konversi lahan pertanian menjadi non pertanian telah mengancam produksi pangan nasional. Seiring adanya peningkatan jumlah penduduk, kompetisi pemanfaatan lahan untuk berbagai kebutuhan juga semakin meningkat. Di sisi lain, Rencana Tata Ruang Wilayah Kabupaten/Kota (RTRWKK) yang tidak memperhatikan kepentingan kawasan penyangga pangan juga membuka peluang menggerus lahan pertanian [5].

Kondisi tersebut menjadi ancaman serius bagi peningkatan produksi pangan. Terlebih ada sekitar 3 juta hektar lahan sawah irigasi dan non irigasi yang terancam dikonversi ke lahan non pertanian. Sebagai gambaran saja, Provinsi Jawa Tengah pada tahun 2019 saja telah mengajukan rencana alih fungsi lahan sawah seluas 214 ribu ha untuk lahan non pertanian. Ini akan berdanpak terjdianya penurunan kapasitas produksi pangan [5].

Dampak buruk lain, konversi lahan pertanian menimbulkan kerugian investasi, 
degradasi agroekosistem, degradasi tradisi dan budaya masyarakat agraris. Bahkan bila dikaitkan dengan isu kesejahteran, semakin sempitnya luas lahan garapan usaha pertanian juga dapat menurunkan kesejahteraan petani, termasuk memunculkan kelangkaan lapangan kerja [5]. Kondisi ini amat ironis ketika jumlah pengangguran di Indonesia menurut data BPS periode Agustus 2020 mengalami peningkatan sebanyak 2,67 juta orang. Jika dilihat berdasarkan lokasi, jumlah pengangguran di kota mengalami peningkatan lebih tinggi dibandingkan di desa. Di kota, tingkat pengangguran meningkat 2,69 persen sementara di desa hanya 0,79 persen [6].

Data BPS juga menyebutkan sektor pertanian menyerap tenaga kerja yang cukup besar yakni 35 juta orang pada Februari tahun 2020. Jumlah ini merupakan $20,70 \%$ dari jumlah tenaga kerja Indonesia seluruhnya. Jika dibandingkan dengan bulan Februari tahun 2019 sebesar 35,42 juta orang, maka angka tersebut mengalami penurunan sebesar 1,17\%. Tenaga kerja tersebut didominasi penduduk yang bekerja di subsektor tanaman pangan sebesar 17,22 juta orang $(49,20 \%)$ dari seluruh penduduk yang bekerja di sektor pertanian.

Kontribusi Pertanian Perkotaan terhadap Ketahanan Pangan

Perkembangan dan kemajuan IPTEK melahirkan industri yang membuat sebagian penduduk Indonesia beralih profesi dari petani menjadi pegawai perusahaan karena menghasilkan pendapatan yang lebih pasti dibandingkan petani yang selalu ada resiko gagal panen sehingga tidak ada pendapatan. Industri juga akan meningkatkan pemakaian tanah yang mengakibatkan penurunan luasan lahan pertanian. Lahan-lahan pertanian beralih fungsi menjadi bangunanbangunan dan pemukiman penduduk. Dampak lain akibat industri adalah semakin meningkatnya jumlah penduduk kota akibat berpindahnya penduduk desa ke kota karena lebih berpeluang mendapatkan pekerjaan.

Akumulasi dampak tersebut memunculkan masalah baru, terutama jumlah ketersediaan pangan atau ketahanan pangan dan pencemaran udara. Peralihan profesi dari petani ke pegawai perusahaan mengakibatkan penurunan jumlah petani sehingga terjadi penurunan hasil pertanian. Pemakaian ruang yang bedampak pada penurunan luasan lahan pertanian juga mengakibatkan penurunan hasil pertanian pertahun. Hal ini karena hasil produksi berbanding lurus dengan luas lahan. Selain itu, pertambahan penduduk kota menyebabkan jumlah permintaan pangan meningkat sedangkan peningkatan jumlah permintaan ini tidak seimbang dengan ketersediaan pangan.

Terkait dengan ketersediaan lahan, selama ini budidaya pertanian hanya 
dikembangkan di perdesaan. Sementara jumlah penduduk Indonesia yang tinggal di kawasan perkotaan saat ini telah mencapai 45 persen dari total penduduk keseluruhan dan diperkirakan bakal meningkat hingga mendekati 75 persen pada tahun 2035 mendatang. Peningkatan ini akan mengakibatkan kebutuhan pangan di perkotaan juga semakin meningkat. Salah satu risiko yang bakal dihadapi kawasankawasan perkotaan di masa kini dan masa datang adalah persoalan ketersediaan pangan dan ketersediaan air bersih. Aspek ketahanan pangan menjadi komponen yang sangat krusial bagi kawasan perkotaan di masa depan, termasuk bagi kawasankawasan perkotaan di Indonesia [8]. Saat ini, kawasan perkotaan sangat bergantung pada kawasan perdesaan dan daerah pinggiran kota untuk pasokan bahan makanan, seperti beras, sayur-mayur, buah-buahan, dan laukpauk.

$\begin{array}{ccc}\text { Kawasan } & \text { perkotaan } & \text { juga } \\ \text { menggantungkan } & \text { pasokan } & \text { bahan } \\ \text { makanannya dari } & \text { aktivitas impor. }\end{array}$
Ketergantungan seperti ini sangat tidak menguntungkan dilihat dari aspek ketahanan pangan secara umum. Sekali saja pasokan bahan pangan terganggu, misalnya, maka jaminan ketahanan pangan kawasan perkotaan akan mengalami goncangan.

Di sisi lain, dengan kecenderungan makin meningkatnya laju pertambahan jumlah populasi kawasan perkotaan, penduduk kota dipastikan akan terus mengalami peningkatan. Ketergantungan pasokan bahan pangan kepada kawasan perdesaan dan daerah pinggiran maupun dari aktivitas impor bakal cenderung menyulitkan kondisi perkotaan di masa depan.

Agar ketahanan pangan wilayah perkotaan tetap terjamin maka kawasan perkotaan harus mampu memasok bahan pangannya sendiri untuk mencukupi kebutuhan sebagian besar warganya. Salah satu solusi yang bisa dijalankan adalah pertanian perkotaan.

Pertanian perkotaan merupakan sebuah industri yang memproduksi, memproses, dan menjual bahan makanan dalam rangka memenuhi permintaan harian konsumen dalam kota dan pinggiran kota melalui penerapan metode produksi intensif, menggunakan sumber daya alam dan limbah perkotaan untuk menghasilkan berbagai macam tanaman dan ternak [9]. Teknologi pertanian perkotaan yang bisa dikembangkan adalah vertikultur, hidroponik, aquaponik, vertiminaponik, dan wall gardening.

Pada saat ini, paradigma peran pertanian perkotaan telah bergeser pada tataran peran yang lebih strategis, yakni sebagai pendukung ketahanan pangan dan keamanan pangan kota serta sekitar kota. Dukungan tersebut dapat dilakukan melalui dua cara. Pertama, meningkatkan jumlah 
makanan yang tersedia untuk orang yang hidup di kota-kota. Kedua, memungkinkan sayuran, buah-buahan, dan produk daging yang aman, sehat, dan segar tersedia untuk konsumen perkotaan [10].

Peran pertanian perkotaan sebagai pendukung ketahanan pangan masyarakat diyakini semakin perlu untuk dikembangkan. Hal tersebut merujuk pada beberapa fakta yaitu sebanyak $50 \%$ dari populasi dunia tinggal di wilayah perkotaan, dan FAO mencatat lebih dari 800 juta orang terlibat dalam pertanian perkotaan di seluruh dunia telah berkontribusi dalam menyuplai makanan untuk penduduk kota. Tidak hanya itu, penduduk berpenghasilan rendah di perkotaan menghabiskan antara 40\%-60\% dari pendapatan mereka untuk makanan setiap tahunnya. Beberapa peneliti di dunia telah meneliti kebutuhan pangan mencapai 6.600 ton per hari, serta tidak kurang 250 juta orang kelaparan di dunia hidup di kotakota. Diperkirakan pada tahun 2035, 65\% penduduk akan menghuni perkotaan, terutama di 16 kota besar di Indonesia [10].

Pertanian perkotaan tidak hanya sekedar menanam sayur atau buah saja. Dikutip dari laman simplicable.com dan online.aurora.ed $u$, ada banyak jenis pertanian perkotaan yang bisa kamu coba. Beberapa diantaranya adalah vertikultur, taman dinding, taman rooftop, hidroponik, akuaponik, pertanian indoor (indoor farming), rumah kaca (greenhouse), kebun komunitas ( community garden), dan masih banyak lagi. Selain itu, skala pertanian perkotaan pun bervariasi, mulai dari skala rumah tangga hingga skala komersial. Di beberapa daerah, peternakan merupakan bagian penting dari pertanian perkotaan.

Penerapan pertanian perkotaan akan mengurangi rantai waktu transportasi bahan pangan. Sebagaimana diketahui, sebagian besar bahan pangan harus melewati perjalanan yang tidak singkat untuk sampai ke para konsumen di daerah perkotaan. Jarak yang panjang itu akan mempengaruhi kesegaran serta kualitas nutrisi bahan pangan. Belum lagi soal kebutuhan bahan bakar minyak (BBM) untuk kendaraan yang mengangkutnya, yang pada akhirnya ikut mempengaruhi penetapan harga bahan pangan.

Pertanian perkotaan telah terbukti berhasil di negara-negara maju yang bahkan negara yang lahan pertaniannya lebih sedikit dari pada Indonesia. Situs fao.org menyatakan bahwa ada sekitar 200 juta petani pertanian perkotaan di dunia yang mampu menyuplai makanan ke 700 juta orang, yaitu sekitar 12 persen populasi dunia. Laman tersebut juga menyebutkan bahwa pertanian perkotaan menyediakan 30 persen konsumsi sayuran di Kathmandu, 50 persen di Karachi, dan 85 persen di Shanghai. Di negara-negara berkembang, komoditas pertanian perkotaan seperti 
buah, sayuran, dan ternak mampu memenuhi 10-40 persen kebutuhan gizi keluarga di perkotaan. Dengan begitu, pertanian perkotaan sebenarnya berperan besar bagi ketahanan pangan khususnya di perkotaan.

Implementasi pertanian perkotaan yang dilakukan secara penuh di setiap kota besar dunia akan menghasilkan 180 juta ton bahan makanan selama setahun. Angka tersebut merupakan 10 persen dari total hasil produksi makanan secara global. Tidak hanya itu, pertanian perkotaan juga berpotensi menghemat 15 miliar kilowatt per jam untuk pemakaian energi dunia selama setahun dan menghasilkan 170.000 ton nitrogen ke udara, sama artinya dengan mencegah turunnya 57 juta meter kubik limpasan badai yang kerap mencemari sungai dan saluran air bersih [12].

Pertanian perkotaan tidak hanya berperan menyediakan kebutuhan pangan perkotaan tetapi juga mengurangi sampah, mengurangi polusi udara dan suara, mengurangi cemaran logam dan kimia, menambah nilai estika kota, memberikan pemasukan tambahan, dan mengurangi tingkat stres dan perbaikan hubungan sosial [10].

Potensi Lansia Mengembangkan Pertanian Perkotaan

Berdasarkan data Kementan tahun 2020, kelompok usia 60 tahun ke atas yang bekerja di sektor pertanian adalah 7,38 juta orang. 6,36 persen bekerja di sub sektor tanaman pangan; 2,24 persen di sub sektor perkebunan; $1,58 \%$ di sub sektor peternakan; 0,96 persen di sub sektor hortikultura 0,96\%. Data ini menunjukkan bahwa lansia masih berperan besar mendukung sektor pertanian di Indonesia.

Tidak hanya pertanian konvensional di perdesaan, lansia juga berpotensi untuk mendukung ketahanan pangan perkotaan melalui aktivitas pertanian perkotaan mengingat data BPS tahun 2019 menunjukkan bahwa populasi lansia di perkotaan justru lebih tinggi dibandingkan di perdesaan. Terdapat lima kota besar di Indonesia yang memiliki populasi lansia tinggi yaitu D.I. Yogyakarta (14,5 \%); Jawa Tengah (13,36\%); Jawa Timur (12,96\%); Bali $(11,30 \%)$; Sulawesi Utara (11,15\%). Potensi tersebut sangat mungkin direalisasikan bila ada komitmen bersama dari komunitas lansia, Kementerian terkait serta dukungan swasta.

Yang tak kalah penting adalah adanya roadmap bagi pengembangan pertanian perkotaan yang dilakukan para lansia. Roadmap bisa menjadi guidance (acuan) baik terkait jenis tanaman, masa tanam, pasca tanam hingga pemasaran. Tentunya dalam penyusunan roadmap ini harus tetap memperhatikan karakteristik dan kendala yang pada umumnya kerap dialami para lansia. Ingat, lansia memnag bisa produktif meski usianya tidak lagi usia produktif. Jika 
hasil pertanian perkotaan bisa mendatangkan tambahan pendapatan bagi lansia, tentu akan menambah semangat, meski ada manfaat lain, bukan semata demi rupiah.

\section{Manfaat Pertanian Perkotaan bagi Lansia}

Berkebun merupakan salah satu aktivitas pertanian perkotaan yang dapat dilakukan oleh lansia di perkotaan. Kegiatan menggali tanah, menanam, menyiram, mengolah bahan pangan menjadi makanan, menikmati sentuhan, berkreasi dan hobi dalam aktivitas berkebun bagi lansia akan menyehatkan fisik maupun mental lansia.

1. Menurunkan tingkat stres

Kegiatan berkebun dapat
menurunkan kadar kortisol yang dapat
mengurangi stres dan bahkan menurunkan
tekanan darah tinggi. Kegiatan berkebun
mampu menurunkan kortisol,sehingga
menyebabkan suasana hati yang positif.
Berada di bawah sinar matahari dan
menciptakan tempat yang indah untuk
beristirahat dan bersantai juga akan
membawa kedamaian dan mengurangi
kecemasan.

\section{Meningkatkan serotonin}

Serotonin adalah bahan kimia di otak yang dapat meningkatkan suasana hati serta perasaan tenang dan damai. Kegiatan berkebun dapat mengurangi gejala depresi. Kontak dengan bakteri tertentu di tanah memicu pelepasan serotonin di otak dan bekerja sebagai antidepresan alami. Oleh karena itu, terapi hortikultura yang dilakukan menunjukkan hasil positif bagi orang dengan depresi dan penyakit mental lainnya.

3. Meningkatkan kesehatan jantung dan mengurangi risiko stroke

Berkebun adalah olahraga yang cukup intens dan dapat dihitung sebagai olahraga yang direkomendasikan 30 menit setiap hari. Berkebun secara teratur dapat mengurangi risiko serangan jantung dan stroke sebanyak 30 persen untuk orang berusia di atas 60 tahun. Selain itu, berada di luar di taman yang cerah dapat meningkatkan kadar vitamin $D$ dan mengurangi risiko penyakit jantung.

4. Meningkatkan mobilitas

Selain menjadi bentuk latihan fisik yang hebat, berkebun dapat meningkatkan mobilitas dan kekuatan. Dengan menjaga otot yang jarang digunakan, berkebun telah terbukti menjadi cara yang produktif untuk membangun kembali kekuatan dan mobilitas setelah terkena stroke.

5. Meningkatkan kesehatan otak

Meskipun penyebab dan cara pencegahan Alzheimer belum diketahui, namun menjalankan hidup dengan pikiran yang positif dapat menurunkan resiko terserang penyakit. Berkebun adalah salah satu pilihan gaya hidup yang dapat mengurangi risiko Alzheimer dan demensia. Dengan melibatkan fungsi penting seperti ketangkasan, pemecahan masalah, daya 
tahan, dan kesadaran sensorik. Berkebun dapat mengurangi risiko demensia sebanyak 36 persen.

6. Meningkatkan kebutuhan nutrisi dan gizi Jenis produk pertanian perkotaan sangat beragam seperti sayuran, buahbuahan, dan lauk pauk yang dibudidayakan sendiri sehingga memiliki kandungan gizi yang baik dan tentu saja lebih segar. Bahanbahan yang digunakan dalam pertanian perkotaan pada umumnya adalah bahan organik yang tidak berdampak negatif bagi kesehatan.

\section{Model-Model Pertanian Perkotaan}

Terdapat beragam model pertanian perkotaan yang dapat diterapkan oleh lansia namun secara umum bentuk vertikal merupakan model yang paling ideal untuk mengurangi aktivitas membungkuk dan berjongkok yang terlalu lama pada lansia. Jenis tanaman yang dapat dibudidayakan menggunakan teknologi pertanian perkotaan adalah sayuran daun, sayuran buah, tanaman herbal, dan buah-buahan yang tumbuh merambat. Wadah yang digunakan bisa pot, botol plastik bekas, pipa paralon, talang air, polibag, kaleng susu, kaleng cat, dan sebagainya.

Umumnya kegiatan pertanian perkotaan dilakukan secara organik. Pertanian perkotaan tidak hanya memproduksi tanaman tetapi juga hewan seperti kelinci dan ikan. Kotoran hewan dapat dimanfaatkan sebagai pupuk bagi tanaman.

1. Hidroponik

Hidroponik adalah budidaya tanaman tanpa menggunakan tanah. Media tanam yang digunakan dapat berupa sekam bakar, rockwool, cocopeat, kerikil, spons, zeolit, dan sebagainya. Jenis tanaman yang bisa dibudidayakan secara hidroponik sistem vertikultur yaitu tanaman yang ukurannya tidak terlalu besar. Jenis tanaman yang bisa dibudidayakan secara hidroponik antara lain bayam, kangkung, selada, sawi, kemangi, tomat, cabai, bawang merah atau putih, terong, melon, semangka, dan sebagainya. Media tanam serbuk gergaji menghasilkan pertumbuhan tanaman terong yang lebih tinggi dibandingkan arang sekam, zeolit, dan cocopeat yang dibudidayakan menggunakan hidroponik sistem irigasi tetes [16]. 


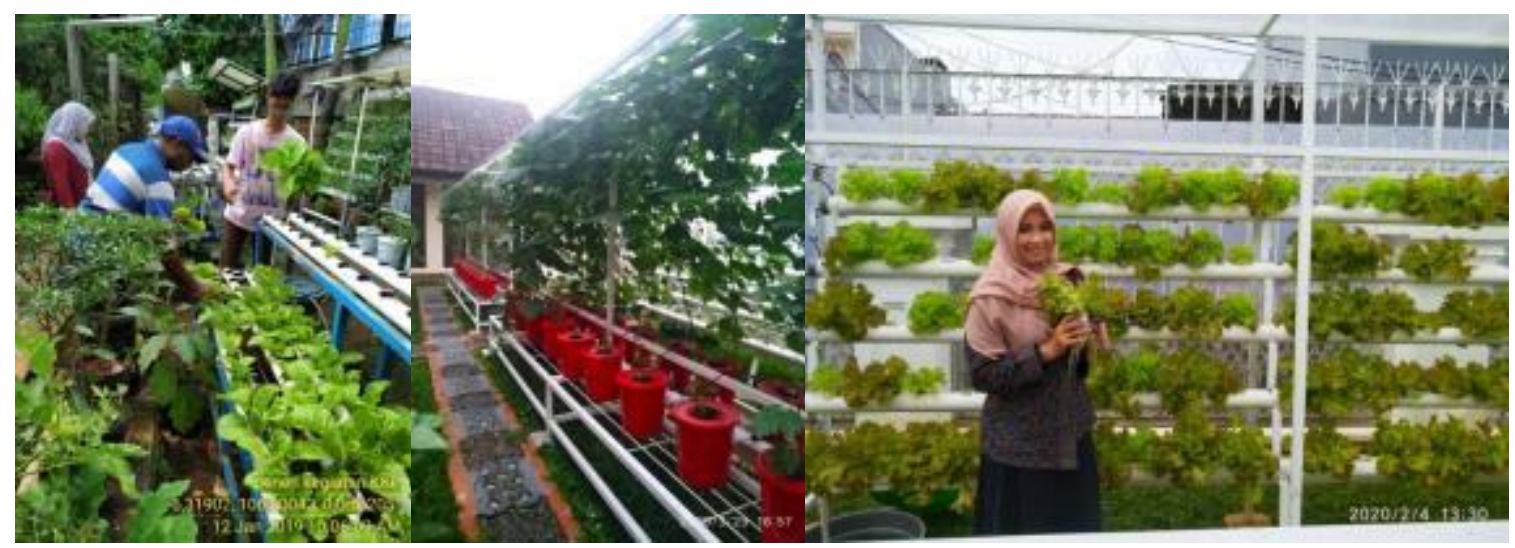

Foto: Dok. Fakultas Pertanian URINDO Jakarta dan Yosep Fadilah

Untuk memudahkan lansia dalam

melakukan budidaya hidroponik maka hidroponik dibuat secara vertikal. Tanaman disusun dalam model bertingkat dari bawah ke atas. Tujuannya untuk mendayagunakan lahan yang luasnya sangat terbatas atau sempit secara lebih optimal. Melalui teknik ini bisa dibudidayakan sekitar 30 tanaman di lahan yang luasnya hanya sekitar 50 × $50 \mathrm{~cm}$ saja.

Demikian pula dengan sistemnya, dapat diselaraskan sesuai dengan keinginan dan kebutuhan. Misalnya wick system atau sistem sumbu, Nutrient Film Technique, Deep Floating Technique, fertigasi atau dutch bucket. dapat digunakan sebagai media tanam tanaman Kemudian untuk tempat peletakannya bisa memilih pagar, menyusun talang air atau pipa paralon secara bertingkat atau membuat rak.

\section{Akuaponik}

Akuaponik merupakan sistem budidaya yang memadukan pemeliharaan ikan dengan menanam sayuran secara hidroponik. Hasil dari panen akuaponik tentunya cukup untuk memenuhi kebutuhan pangan, khususnya untuk skala rumah tangga. Ini disebabkan, panen sudah mencakup kebutuhan pangan nabati dan hewani. Bahkan, dalam setiap satu kali siklus panen ikan saja, kita bisa mendapatkan 2-3 kali panen tanaman sayuran [17].

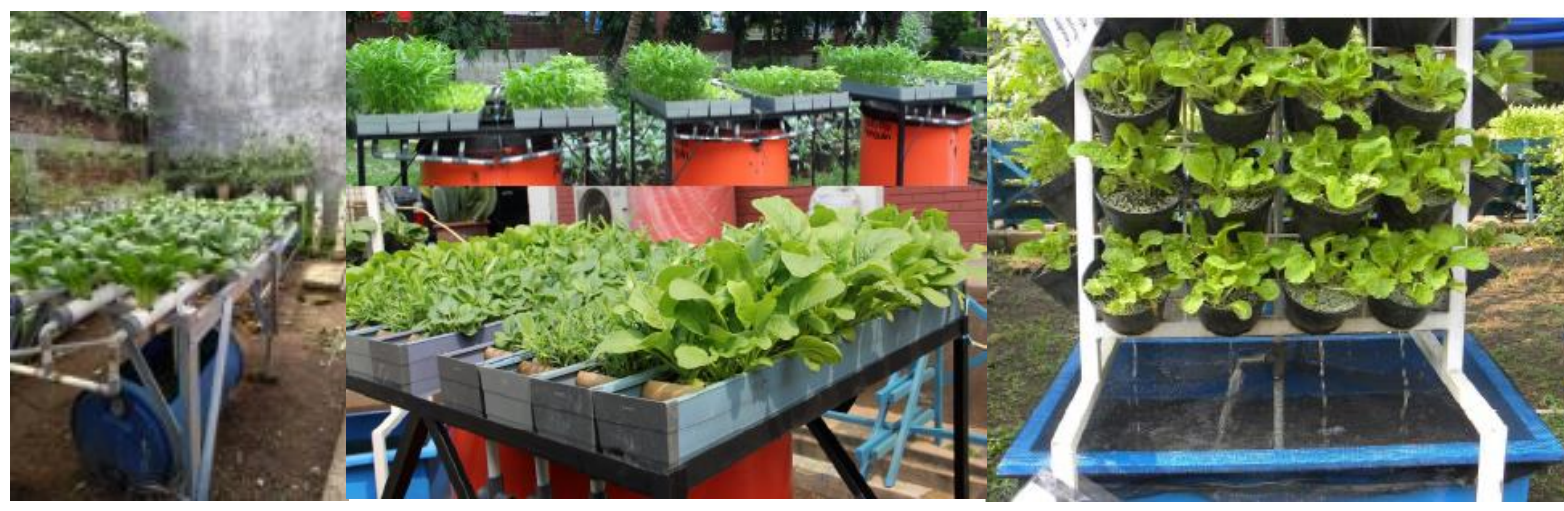

Foto: Dok. Fakultas Pertanian URINDO Jakarta dan BPTP DKI Jakarta 
Keunggulan sistem budidaya akuaponik diantaranya dapat diterapkan di pekarangan sempit, tidak memerlukan media tanam, pupuk, penyiraman, hemat air, sehat, memiliki nilai estetika tinggi, dan bebas kontaminan. Jadi, akuaponik sangat prospektif untuk dikembangkan di tempat dimana air dan tanahnya langka serta mahal, seperti di wilayah perkotaan, di daerah kering, padang pasir, serta pulaupulau kecil [10].

Untuk akuaponik sederhana, bisa menggunakan wadah dari bak fiber, kolam terpal, kolam plastik, akuarium bekas, hingga kolam tanah untuk wadah budidaya ikan, sedangkan untuk wadah budidaya tanaman bisa terbuat dari bambu atau paralon. Jenis tanaman yang bisa dibudidayakan menggunakan akuaponik adalah tanaman sayuran daun, tanaman sayuran buah dan tanaman herbal. Tanaman sayuran buah tomat yang dibudidayakan secara akuaponik menggunakan media tanam kerikil, zeolit, dan batu apung menghasilkan pertumbuhan dan produksi yang lebih tinggi dibandingkan tanaman cabai dan terong [18]. Jenis ikan yang dipilih bisa berupa ikan konsumsi seperti lele, mas, dan ikan hias seperti koi dan komet [17]. Ikan gurame dan nila bisa digunakan dalam sistem akuaponik [18].

3. Vertikultur
Vertikultur dapat diartikan sebagai teknik budidaya tanaman menggunakan media tanah yang disusun secara vertikal sehingga penanaman dilakukan secara bertingkat. Teknik budidaya ini tidak memerlukan lahan yang luas, bahkan dapat dilakukan pada rumah yang tidak memiliki halaman sekalipun. Salah satu solusi untuk masyarakat dapat mengembangkan pertanian untuk memenuhi kebutuhan keluarga dengan menanan tanaman secata vertikultur [19].

Sistem vertikultur dapat dilakukan secara indoor maupun outdoor. Sistem budidaya pertanian secara vertikal atau bertingkat ini merupakan konsep penghijauan yang cocok untuk daerah perkotaan dan lahan terbatas [20]. Sistem vertikultur merupakan cara pemanfaatan lahan secara efisien yang menerapkan prinsip utama penghematan ruangan dimana tanaman ditata dalam wadah atau bangunan yang bertingkat sehingga tanaman dapat diatur secara bersusun menggunakan rak tanaman sesuai kebutuhan. Kekurangan sistem vertikultur adalah membutuhkan perawatan yang teratur dan bila tanaman dipindahkan tidak hati-hati, maka tanaman mudah rusak, patah, dan bahkan tanaman akan mati [21]. Persyaratan vertikultur adalah kuat dan mudah dipindah-pindahkan. Tanaman yang akan ditanam sebaiknya disesuaikan dengan 
kebutuhan dan memiliki nilai ekonomis tinggi, berumur pendek, dan berakar pendek. Contoh budidaya tanaman secara vertikultur adalah vertikultur talang atau paralon, vertikultur pot atau polibag, dan wall garden.

Sistem vertikultur merupakan cara pemanfaatan lahan secara efisien yang menerapkan prinsip utama penghematan ruangan dimana tanaman ditata dalam wadah atau bangunan yang bertingkat sehingga tanaman dapat diatur secara bersusun menggunakan rak tanaman sesuai kebutuhan. Kekurangan sistem vertikultur adalah membutuhkan perawatan yang teratur dan bila tanaman dipindahkan tidak hati-hati, maka tanaman mudah rusak, patah, dan bahkan tanaman akan mati [21].

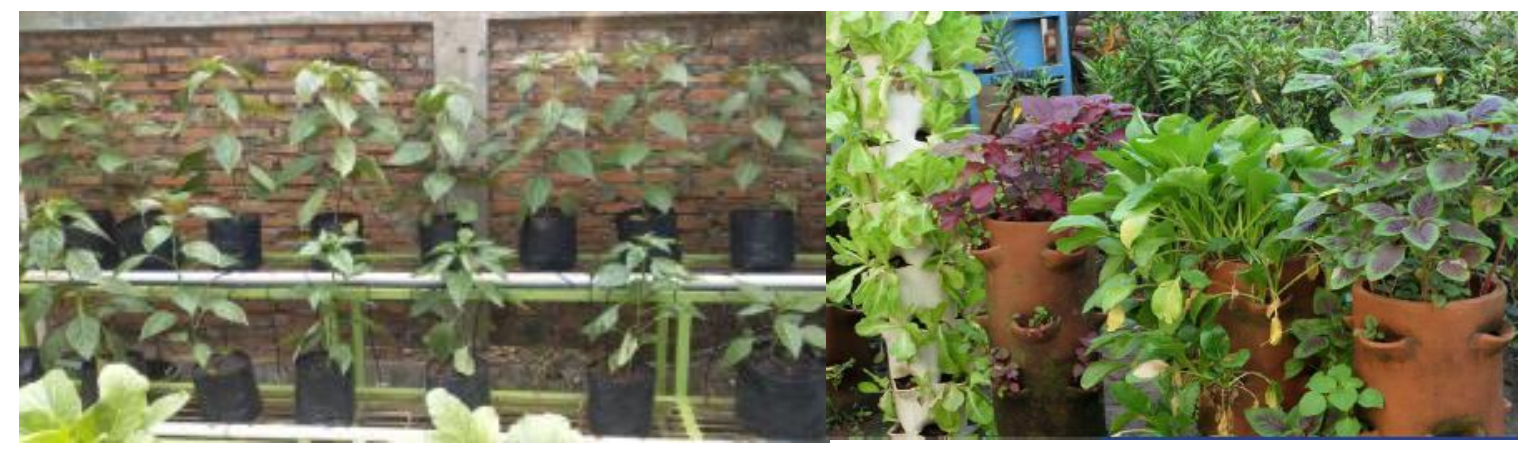

Foto: Dok. Fakultas Pertanian URINDO Jakarta dan BPTP DKI Jakarta

Vertikultur sangat sesuai untuk sayuran seperti bayam, kangkung, kucai, sawi, selada, kenikir, seledri, cabai, tomat, terong, dan lainnya. Namun, untuk budidaya vertikultur yang menggunakan wadah paralon dan bambu kurang sesuai untuk sayuran buah seperti cabai, terong, tomat, pare dan lainnya. Hal ini disebabkan dangkalnya wadah pertanaman sehingga tidak cukup kuat menahan tumbuh tegak tanaman.

\section{Roof Garden}

Roof garden atau taman atap rumah dikenal sebagai solusi menciptakan lahan terbuka hijau di lahan terbatas. Saat lahan di depan, samping, dan belakang rumah tidak cukup lagi dibuat taman, maka area kosong di bagian atas rumah dapat dimanfaatkan. Namun, pembuatan roof garden memerlukan biaya yang tidak sedikit dan perencanaan desain yang matang. Mulai dari kekuatan fondasi bangunan, sistem tanam, pengairan, dan drainase perlu dipersiapkan dengan baik.

Tanaman dapat dibudidayakan secara vertikultur, hidroponik, maupun akuaponik. Tanaman yang dibudidayakan bisa berbagai jenis seperti tanaman hias, tanaman sayuran, tanaman buah maupun tanaman obat. 


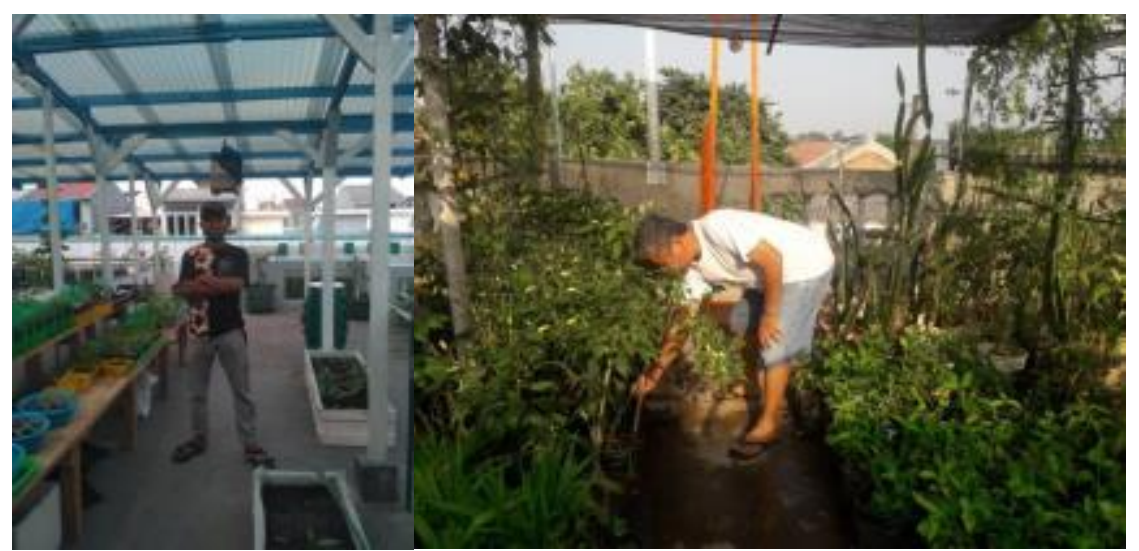

Foto: Dok. Gordianus Amuro dan Fakultas Pertanian URINDO Jakarta

Roof garden memiliki banyak manfaat yaitu dapat mengurangi penggunaan penyejuk ruangan dan menghemat pemakaian listrik sebanyak $50-70$ persen karena bisa mengurangi 10-25 persen udara panas yang masuk ke dalam rumah; mengurangi radiasi sinar matahari secara efektif, sehingga melindungi struktur eksterior rumah atau bangunan dari resiko kerusakan fisik bangunan, seperti pelapukan dan kebocoran atap; menyimpan 30 persen air hujan; memperbaiki kualitas lingkungan hidup dan memengurangi pemanasan global; meredam suara bising; menyaring udara kotor dari luar rumah; dan tempat relaksasi bagi penghuninya [22].

\section{Microgreen}

Microgreen merupakan istilah bagi tanaman yang dipanen pada saat semai tanam berumur muda yaitu, sekitar 7 sampai dengan 14 hari setelah semai. Microgreen pada dasarnya mempunyai nutrisi kandungan vitamin, mineral dan betakaroten yang lebih tinggi daripada sayuran yang sama pada saat dewasa. Daun tumbuhan yang masih baru ini mengandung banyak minyak nabati dan protein yang akan digunakan tanaman tersebut untuk tumbuh, melindungi diri agar tetap terjaga dan kuat sampai proses perkecambahan dimulai [23].

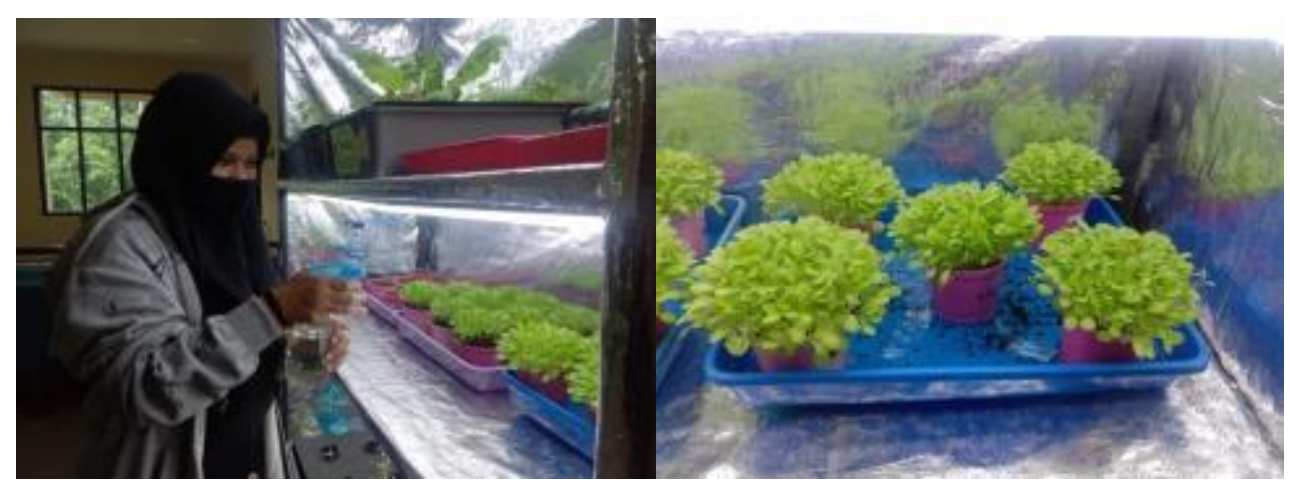

Foto: Dok. Fakultas Pertanian URINDO Jakarta 
Media tanam yang dapat digunakan dalam budidaya microgreen adalah bahan organik maupun non organik. Bahan organik yang dapat digunakan sebagai media tanam antara lain kompos kulit bawang merah dan kotoran kelinci. Kedua kompos tersebut telah diaplikasikan sebagai media tanam bagi microgreen sorgum (wheatgrass) [24]. Media non organik juga dapat dimanfaatkan sebagai media tanam pada budidaya microgreen seperti rockwool, perlite, dan vermikulit. Jenis tanaman microgreen yang bernilai tinggi adalah bayam, asian greens, kemangi, bit, brokoli, sorgum, kubis, wortel, seledri, lobak, serai, ketumbar, bawang dan peterseli.

\section{KESIMPULAN}

Kebutuhan pangan yang semakin tinggi menuntut upaya pemberdayaan lansia dengan melakukan pertanian perkotaan sudah harus direalisasikan secara nasional dan berkelanjutan. Langkah ini bukan lagi sekedar mendukung ketahanan pangan tetapi juga membangun ekonomi masyarakat lansia. Terlebih bila dikaitkan dengan pemenuhan gizi keluarga. Banyak pilihan pertanian perkotaan yang sesuai dengan lansia agar dapat memproduksi hasil pertanian di wilayah perkotaan, seperti teknik hidroponik, akuaponik, vertikultur, roof garden, dan microgreen. Pengembangan pertanian dengan lahan sempit perkotaan dipercaya dapat menjadi solusi permasalahan pangan akibat dari turunnya jumlah petani, urbanisasi, dan keterbatasan lahan.

\section{DAFTAR PUSTAKA}

Maylasari, I., Y. Rachmawati., H. Wilson., S.W. Nugroho., N.P. Sulistyowati., dan F.W.R. Dewi. 2019. Statistik Penduduk Lanjut Usia 2019. Badan Pusat Statistik.

Purwoko, K. 2010. Penduduk Indonesia akan Mencapai 440 Juta Jiwa. https://republika.co.id/berita/124387 /penduduk-indonesia-akan-mencapai440-juta-jiwa. Diakses pada 12 Januari 2021.

Nasution, D. D. 2020. Tiap Tahun, 60 Ribu Hektare Lahan Pertanian Menyusut. https://republika.co.id/berita/q411u4 370/tiap-tahun-60-ribu-hektarelahan-pertanian-menyusut. Diakses pada 12 Januari 2021.

Triwulan, E. 2018. Target Swasembada Pangan Pemerintah Tidak Didukung Luas Lahan yang Memadai. https://id.cipsindonesia.org/post/targetswasembada-pangan-pemerintahtidak-didukung-luas-lahan-yangmemadai. Diakses pada 12 Januari 2021.

Andri, K. B. 2020. Konversi Lahan Pertanian, 
Lawan!

https://kilaspapua.com/opini/konvers

i-lahan-pertanian-lawan/. Diakses pada 12 Januari 2021.

Fauzia, M. 2020. Indonesia Resesi, Jumlah Pengangguran Naik Jadi 9,77 Juta Orang.

https://money.kompas.com/read/202

0/11/05/141654326/indonesia-resesijumlah-pengangguran-naik-jadi-977juta-orang. Diakses pada 12 Januari 2021.

Subinarto, D. 2019. Membangun Pertanian Kota.

https://news.detik.com/kolom/d4444353/membangun-pertaniankota. Diakses pada 12 Januari 2021.

Food Agriculture Organization (FAO). 2009. Urban and Peri-Urban Agriculture. Household Food Security and Nutrition.

Sastro, Y. 2016. Teknologi Akuaponik Mendukung Pengembangan Urban Farming. Balai Pengkajian Teknologi Pertanian (BPTP) Jakarta.

Macharani, M.A. 2019. Mewujudkan Jakarta Semakin Hijau dan Menjaga Ketahanan Pangan Lewat Urban Farming.

https://www.beritajakarta.id/read/70

031/mewujudkan-jakarta-semakin-

hijau-dan-menjaga-ketahanan-

pangan-lewat-urban-

farming\#.X_4LW4zaM8. Diakses pada 14 Januari 2021.

Fandi, A. A., R. Muchtar. dan Notarianto. 2020. Pengaruh Media Tanam terhadap Pertumbuhan Tanaman Terong (Solanum melongena L.) dengan Sistem Hidroponik. Jurnal Ilmiah Respati. 11 (2): 114-127.

Maulana, A. 2020. Akuaponik, Pilihan Budidaya Rumahan di Kala Pandemi. https://www.unpad.ac.id/2020/12/ak uaponik-pilihan-budidaya-rumahandi-kala-pandemi/. Diakses pada 12 Januari 2021.

Suryani dan R. Nurjasmi. 2016. Pengaruh Jenis Ikan dan Media Tanam terhadap Pertumbuhan dan Hasil Tanaman Sayuran Buah pada Sistem Akuaponik. Jurnal IImiah Respati. 7 (2): 626-635.

Hidayati, N., P. Rosawanti., F. Arfianto., dan N. Hanafi. 2018. Pemanfaatan Lahan Sempit untuk Budidaya Sayuran dengan Sistem Vertikultur. Pengabdianmu. 3 (1): 40-46.

Sulaeman, A. Dan R. Nurjasmi. 2017. Respon Tanaman Pakcoy terhadap Tandan Kosong Kelapa Sawit pada Sistem Vertikultur. Jurnal IImiah Respati Pertanian. 11 (2): 713-717.

Putra, J.L., S.M. Sholihah., dan Suryani. 2019. Respon Pertumbuhan dan Hasil Beberapa Jenis Tanaman Sayuran Terhadap Pupuk Kotoran Jangkrik dengan Sistem Vertikultur. Jurnal Ilmiah Respati Pertanian. 10 (2): 115- 
Jurnal IImiah Respati

125.

Kania. 2018. Selain Menghijaukan Lahan Sempit, Ini 7 Fungsi Lain Dari Roof Garden! https://www.dekoruma.com/artikel/7 5537/manfaat-roof-garden. Diakses 12 Januari 2021.

Ashofah, U.N., N.W. Rahmatika., S.R. Ulfa., S. Setyorini., dan E. Rusdiyana. 2019. Strategi Diseminasi Inovasi Microgreens di Balai Besar Pengkajian dan Pengembangan Teknologi Pertanian (BBP2TP). Seminar Nasional Dalam Rangka Dies Natalis UNS ke-43.
Arifiansyah, S., R. Nurjasmi, dan R. Muchtar. 2020. Pengaruh Pupuk Organik terhadap Pertumbuhan dan Kandungan Klorofil Wheatgrass (Triticum Aestivum L.). Jurnal IImiah Respati Pertanian. 11 (2): 82-92. 